\title{
Physicochemical characteristics and antioxidant activities of solvent fractions from ethanol extract of Wasabia koreana Nakai leaf
}

\author{
Da Young Kang, Emmanuel Hitayezu, In Hye Han, Ji Su Kim, \\ Young Min Jo, Yoon-Han Kang* \\ Department of Food Processing and Distribution, Gangneung-Wonju National University, Gangneung 25457, Korea
}

\section{고추냉이 잎의 에탄올 추출물로부터 용매분획물의 이화학적 특성 및 항산화 활성}

\author{
강다영 · 히타예주 엠마누엘 · 한인혜 · 김지수 · 조영민 · 강윤한* \\ 강릉원주대학교 식품가공유통학과
}

\begin{abstract}
This study was conducted to investigate the physicochemical properties and antioxidant activity of the solvent fractions obtained from $80 \%$ ethanol extracts of Wasabia koreana Nakai leaves. From the ethanol extracts, hexane, chloroform, ethyl acetate, and n-butanol fractions were sequentially extracted and collected, and further used for the investigation. The highest yield was obtained in the water fraction and its $\mathrm{pH}$ was 4.25. The total polyphenol, total flavonoid and total pectin contents in the ethyl acetate fraction were $56.24 \mathrm{mgGAE} / \mathrm{g}, 97.29 \mathrm{mgNE} / \mathrm{g}$ and $108.8 \mathrm{mg} / \mathrm{g}$, respectively. This indicated that the extraction yields of the phenolic compounds and pectin in the solvent fractions obtained from the Wasabi leaves and petiole were significantly different. Analysis of the taste components of the ethyl acetate and water fractions was carried out using an electronic tongue sensor. A negative concentration-dependent population for the ethyl acetate fraction and a positive population for the water fraction, corresponding to DF1 $(83.96 \%)$ in the discriminant function analysis (DFA) plot, were confirmed from the analysis. In the ethyl acetate fraction, the $\mathrm{IC}_{50}$ values of 1,1-diphenyl-2-picrylhydrazyl(DPPH) radical scavenging activity and 2,2'-azino-bis(3-ethylbenzothiazoline-6-sulfonic acid(ABTS) radical scavenging activity were $899.88 \mathrm{ppm}$ and $276.63 \mathrm{ppm}$, respectively. Therefore, the ethanol extracts and fractions from Wasabia koreana Nakai leaf have low utilization, which will be beneficial for the development of high value-added products via improvement in the taste components and antioxidant activity.
\end{abstract}

Key words : Wasabia koreana Nakai leaf, solvent fractions, polyphenol, electronic tongue, antioxidant activity

\section{서 론}

십자화과에 속하는 고추냉이는 유럽이 원산지인 서양산 고추냉이(horseradish, Armoracia rusticana), 일본산 고추냉 이(wasabi, Wasabia japonica Matsum), 한국산 고추냉이

*Corresponding author. E-mail : yhkang@gwnu.ac.kr Phone : 82-33-640-2966, Fax : 82-33-640-2966

Received 22 February 2019; Revised 12 July 2019; Accepted 18 July 2019.

Copyright (c) The Korean Society of Food Preservation. All rights reserved.
(Wasabia koreana Nakai) 등으로 예로부터 생선의 비린내를 없애고 식미를 향상시키며 항균작용과 항산화 활성을 목적 으로 식품으로 애용되었다. 그 대표적인 성분은 glucosinolate 화합물의 일종인 sinigrin과 가수분해물인 allyl isothiocyanate 가 대표적이다(1). 고추냉이 잎의 성분 중 isoflavone glycosides 등 플라보노이드(2), 서양고추냉이 잎의 메탄올 추출물의 kaempferol 배당체 추출(3) 뿐만 아니라 고추냉이 잎의 용매 분획별 phenylpropanoid glycosides (4)를 분리하 여 배당체 형태로 각종 페놀성 화합물에 대한 성분이 이루 어졌다. 이들 화합물은 세포벽을 구성하는 cinnamic acids계 열의 페놀산 유도체 및 플라보노이드로 열수 혹은 알코올에 
의한 추출물의 수율 및 조성에 차이가 있다고 생각된다. 페놀성 화합물은 페놀산 및 그 유도체, 플라보노이드, 탄닌 등으로 구성되어 있으며 이러한 성분은 항산화 활성과 비만 억제 등 생리 활성을 가지고 있다(5,6). 고추냉이 부위별 sinigrin과 allyl isothiocyanate 등 매운맛 성분의 함량은 근경 (rhizome), 잎(leaf), 엽병(petiole)의 순으로 많은 것으로 보 고되어 있다(7).

부위별 활용은 근경 분말을 첨가하여 저염 고추장 제조 (8) 등이 있으나 밭고추냉이의 잎 혹은 엽병에 대한 연구는 많이 보고되지 않았다. 특히 고추냉이 잎을 이용한 추출물 로부터 조제한 용매 분획물은 추출수율에 큰 차이를 나타낼 수 있으며, 추출 성분으로는 당, 펙틴, 페놀성 화합물 등 세포벽 구성물질이 주요 성분이라고 할 수 있다. 이들 성분 의 차이는 가공시 농축물의 특성과 항산화 활성 및 관능적 특성에 큰 영향을 주며, 액상차 및 소스 등의 맛에 영향을 줄 수 있으나 농도에 따른 품질 특성 분석은 부족한 실정이 다. 주요 성분 중 페놀성 화합물에 의한 생리 활성 연구에 의하면 참외의 에탄올 추출액의 부위별 항산화 활성은 껍질 부위에서 가장 높게 나타났으며(9), 석류껍질 추출물이 새 우의 저장 중 품질 특성 향상(10), 황금 $80 \%$ 에탄올 추출물 의 ethyl acetate 분획에서 우수한 항산화 활성(11) 등을 보고 하였다. 따라서 유효성분만을 추출하여 용매 분획물의 농 도에 따른 품질 특성 연구가 지속적으로 이루어져야 한다고 생각된다.

앞서 고추냉이에 대한 다수의 연구가 이루어져 있으나 대부분이 부위 중 근경에 집중되어 있으며 다양한 영양성분 이 함유된 잎과 엽병 부위를 활용한 보고는 제한되어 있다. 선행 연구에서 고추냉이 잎과 엽병의 물 추출물의 이화학적 특성과 항산화 활성분석에 대한 연구(12)가 있다.

본 연구는 엽병을 포함한 고추냉이 잎 $80 \%$ 에탄올 추출 물로부터 각종 용매 분획물의 특성을 조사하여 고부가가치 제품의 개발을 위한 기초자료로 활용하고자 한다.

\section{재료 및 방법}

\section{실험 재료}

용매 분획물을 제조하기 위한 고추냉이 잎은 강원도 태 백에서 2018년 11월에 구입한 것으로 잎과 엽병을 합쳐 $55^{\circ} \mathrm{C}$ 에서 16 시간 열풍건조하여 분쇄 후 시료로 하였다.

\section{고추냉이 잎 $80 \%$ 에탄올 추출물의 용매 분획}

고추냉이 잎 $80 \%$ 에탄올 추출물의 제조는 고추냉이 잎 분말시료 $50 \mathrm{~g}$ 에 $80 \%$ 에탄올 $2,000 \mathrm{~mL}$ 를 첨가하여 실온에 서 1시간 추출한 후 여과지(Whatman No.2)로 여과하였다. $80 \%$ 에탄올 추출물을 감압회전농축기(SB-1100, Rikakikai Co., Ltd, Tokyo, Japan)을 이용하여 농축시켰다. 각 분획물
의 제조는 $80 \%$ 에탄올추출물에 n-hexane, chloroform, ethyl acetate, n-butanol을 용매로 순차 추출하여 잔류 물 분획을 포함한 분획물을 감압회전농축기(SB-1100, Rikakikai Co., $\mathrm{Ltd}$ 를 사용하여 용매를 모두 제거한 후 실험시료로 하였다.

\section{수율, 탁도 및 $\mathrm{pH}$}

고추냉이 잎 용매 분획물의 수율 측정은 $\operatorname{Kim}$ 과 $\operatorname{Kim}(13)$ 의 방법에 준하여 용매를 완전히 제거한 후 무게를 측정하 였다. 탁도와 $\mathrm{pH}$ 분석에 사용한 시료의 농도는 $500 \mathrm{ppm}$ 의 단일 농도로 조제하였다. 탁도의 경우 건조한 n-hexane 분 획물은 dimethyl sulfoxide(DMSO) $3 \mathrm{~mL}$ 에 용해 후, 기타 chloroform, ethyl acetate, n-butanol, water 분획물은 단일 용매인 증류수로 용해 후 각 분획을 증류수 $100 \mathrm{~mL}$ 정용하 고 희석을 반복하여 $500 \mathrm{ppm}$ 농도로 조제한 시료로 분광광 도계(Cary8454 UV-Vis, Agilent Technologies, Santa Clara, USA)를 이용하여 $600 \mathrm{~nm}$ 에서 흡광도를 측정하였다(14). 추출물의 $\mathrm{pH}$ 는 Lee 등(15)의 방법에 준하여 각각 추출한 여과물을 pH meter(pH 210, Hanna, Woonsocket, RI, USA) 로 측정하였다.

\section{총 폴리페놀, 총 플라보노이드 및 총 펙틴}

추출물중 총 폴리페놀 함량의 측정은 Pinto 등(10)의 방법 에 따라 시료 $0.25 \mathrm{~mL}$ 에 Folin-ciocalteu 시약 $0.25 \mathrm{~mL}$, 증류수 $2 \mathrm{~mL}$ 를 각각 첨가하여 실온에서 3 분 동안 정치한 후 $20 \% \mathrm{Na}_{2} \mathrm{CO}_{3} 0.25 \mathrm{~mL}$ 를 첨가여 수조에서 $37^{\circ} \mathrm{C}, 30$ 분간 반응 후 흡광도를 분광광도계(Cary8454 UV-Vis, Agilent Technologies)를 이용하여 $750 \mathrm{~nm}$ 에서 측정하였다. 이때 사용한 표준물질은 gallic acid(Sigma-Aldrich Co., St. Louis, $\mathrm{MO}, \mathrm{USA}$ )로 검량곡선으로부터 함량을 산출하였다. 추출 물의 총 플라보노이드 함량은 샘플 $1 \mathrm{~mL}$ 에 diethylene glycol $10 \mathrm{~mL}$ 를 첨가하여 잘 혼합한 후 $1 \mathrm{~N} \mathrm{NaOH} 1 \mathrm{~mL}$ 를 가하여 수옥조에서 $37^{\circ} \mathrm{C}$ 에서 1 시간 반응시킨 후 $420 \mathrm{~nm}$ 에서 흡광 도를 측정하였다. 함량 산출을 위한 플라보노이드 표준물 질은 naringin(Sigma-Aldrich Co.)을 이용하였다.

총 펙틴은 $\mathrm{McComb}$ 과 $\mathrm{McCready}(17)$ 의 방법에 따라 다음 과 같이 정량하였다. 추출물 $0.2 \mathrm{~mL}$ 에 황산 $1.2 \mathrm{~mL}$ 를 첨가 하여 수조에서 $85^{\circ} \mathrm{C}, 5$ 분간 가열하였다. 냉각 후 $0.1 \%$ carbazole $0.1 \mathrm{~mL}$ 첨가하여 vortex mixer로 잘 혼합하고 실온 에서 15 분간 방치한 다음 분광광도계(Cary8454 UV-Vis, Agilent Technologies)를 사용하여 $525 \mathrm{~nm}$ 에서 흡광도를 측 정하였다. 함량 분석을 위한 표준곡선은 농도별 galacturonic acid(Sigma-Aldrich Co.) 용액을 조제 후 작성하 였다.

\section{전자혀 분석}

분획물에 따른 맛의 평가는 전자혀(Astree ㅍ, Alpha MOS., Toulouse, France)를 사용하여 분석하였다. Suh 등 
(18)의 방법에 준하여 실험하였으며 사용한 전자혀 기기 a-Astree 픈 자동식 샘플러와 화학적으로 변형된 $\mathrm{FET}(\mathrm{Chem} \mathrm{FET}$ )에 의한 전위차 적정 센서가 장착되어 있어 보정용 센서(GPS와 SPS)를 이용하여 5가지 맛인 신맛(SRS, sourness), 짠맛(STS, saltiness), 감칠맛(UMS, umami), 단맛 (SWS, sweetness), 쓴맛(BRS, bittreness)을 분석하였다. 고 추냉이 잎 $80 \%$ 에탄올 추출물로부터 각종 용매 분획물의 분석은 용매 분획물 중 ethyl acetate와 물 분획을 각각 100 $\mathrm{ppm}, 50 \mathrm{ppm}, 25 \mathrm{ppm}, 12.5 \mathrm{ppm}, 6.25 \mathrm{ppm}$ 의 농도로 제조 후 샘플 용기에 $25 \mathrm{~mL}$ 를 담아 기기분석에 사용하였다. 맛 성분을 분석하기 위해 전자혀 실험에 사용한 페놀산과 플라 보노이드는 gallic acid, p-hydroxybenzoic acid, naringin, (+)-catechin hydrate(Sigma-Aldrich Co.)를 100 ppm, 50 ppm, $25 \mathrm{ppm}, 12.5 \mathrm{ppm}, 6.25 \mathrm{ppm}$ 의 농도로 제조하였으며, 센서 의 신호 수신 시간은 120 초로 하였다. 모든 시료는 5 회 반복 측정하여 Alpha M.O.S(Toulouse, France)에서 제공된 소프 트웨어(Alphasoft version 12.4 \& Arochembase V4)를 사용 하여 통계처리 하였다.

\section{전자공여능과 $\mathrm{ABTS}$ 라디칼 소거활성 측정}

추출물의 항산화 활성은 전자공여능의 DPPH 라디칼 소 거활성을 측정하였다. DPPH 라디칼 소거활성은 Blois(19) 의 방법에 따라 추출물 $0.2 \mathrm{~mL}$ 에 $0.2 \mathrm{mM}$ 1,1-diphenyl-2picrylhydrazyl(DPPH) $0.8 \mathrm{~mL}$ 를 첨가하여 잘 혼합한 후 10 분간 방치한 다음 분광광도계(Cary8454 UV-Vis, Agilent Technologies)로 $525 \mathrm{~nm}$ 에서 흡광도를 측정하였다. 전자공 여능은 시료 첨가 전후의 흡광도 차이를 백분율(\%)로 산출 하여 나타내었으며, 분획물의 $\mathrm{EDA}(\%)$ 값을 $50 \%$ 감소시키 는 $\mathrm{IC}_{50}$ 값으로 표시하였다. $\mathrm{ABTS}$ 라디칼 소거활성은 $\mathrm{Kim}$ 과 Lee(20)의 방법에 준하여 실험하였다. $7.4 \mathrm{mM}$ 2,2'-azino-bis(3-ethylbenzothiazoline-6-sulfonic acid(ABTS) diammonium salt와 $2.6 \mathrm{mM}$ potassium persulfate를 혼합한 후 radical 형성을 위해 24시간 암소에서 방치하였다. ABTS 용액에 phosphate-buffered saline(pH 7.4)를 희석하여 732 $\mathrm{nm}$ 에서 흡광도가 $0.700 \pm 0.03$ 이 되도록 제조하였다. 시험관 에 추출물 $0.2 \mathrm{~mL}$ 에 $\mathrm{ABTS}$ 용액 $2 \mathrm{~mL}$ 를 첨가하여 암소에서 10 분간 반응시킨 후 분광광도계(Cary8454 UV-Vis, Agilent Technologies)로 $732 \mathrm{~nm}$ 에서 흡광도를 측정하였다. ABTS 라디칼 소거활성은 시료 첨가 전후의 흡광도 차이를 백분율 (\%)로 산출하여 나타내었으며, 분획물의 소거활성(\%) 값을 $50 \%$ 감소시키는 $\mathrm{IC}_{50}$ 값으로 표시하였다. 모든 시료는 3 회 반복 측정하여 평균값으로 나타내었다.

\section{통계처리}

본 연구의 통계분석은 SPSS(Version 21 software, IBM, USA) 통계프로그램을 이용하여 ANOVA를 실시하고 3회 반복으로 실시한 시료 간 평균값을 구하여 Duncan's multiple range test 방법으로 $\mathrm{p}<0.05$ 수준에서 유의성을 검 증하였다.

\section{결과 및 고찰}

\section{수율, 탁도 및 $\mathrm{pH}$}

$80 \%$ 에탄올 추출물을 용매로 분획한 후 각 분획의 수율, 탁도 및 $\mathrm{pH}$ 는 Table 1 과 같다. 고추냉이 분말 $50 \mathrm{~g}$ 을 $80 \%$ 에탄올로 추출 후 수율을 측정한 결과 n-hexane, chloroform, ethyl acetate, n-butanol 및 물 분획물이 각각 $2.30,0.17,0.42$, $2.17,19.32 \%$ 로 물 분획물이 가장 높았는데 이는 원재료 분말인 고추냉이 잎을 이용한 물 추출물의 수율 증진에는 $80 \%$ 에탄올이 적합한 용매인 것으로 생각된다. 물 분획물 의 수율 $19.32 \%$ 는 고추냉이 잎 열수 추출 후 얻은 물분획물 $6.25 \%$ 를 나타내었다는 보고(21)와 같이 분획물 중 가장 높은 것을 알 수 있었다. 각 분획물의 혼탁한 정도를 측정한 탁도는 n-hexane 분획과 chloroform 분획이 각각 $0.11,0.10$ 로 높고, ethyl acetate 분획, 물 분획, n-butanol 분획이 각각 $0.03,0.03,0.01$ 로 낮았데 이러한 탁도 값의 차이는 용매의 양 뿐만 아니라 종류에 따라 지용성, 수용성 성분의 분배능 에 차이가 있는 것으로 생각된다. 각 용매 분획별 $\mathrm{pH}$ 는 물 분획과 $\mathrm{n}$-hexane 분획이 $4.25,4.17$ 로 높고, chloroform 분획은 3.92 였으며, n-butanol 3.60, ethyl acetate 3.53 순으로 낮았다.

Table 1. Yields, turbidity, and $\mathrm{pH}$ of solvent fractions from $80 \%$ ethanol extract of Wasabia koreana Nakai leaf

\begin{tabular}{cccc}
\hline Fraction & Yields $(\%)$ & Turbidity $^{3)}$ & $\mathrm{pH}^{3}$ \\
\hline n-Hexane & $2.30 \pm 0.11^{1) 22}$ & $0.11 \pm 0.01^{\mathrm{b}}$ & $4.17 \pm 0.05^{\mathrm{c}}$ \\
Chloroform & $0.17 \pm 0.03^{\mathrm{a}}$ & $0.10 \pm 0.03^{\mathrm{b}}$ & $3.92 \pm 0.11^{\mathrm{b}}$ \\
Ethyl acetate & $0.42 \pm 0.08^{\mathrm{a}}$ & $0.03 \pm 0.00^{\mathrm{a}}$ & $3.53 \pm 0.10^{\mathrm{a}}$ \\
n-Butanol & $2.17 \pm 0.96^{\mathrm{a}}$ & $0.01 \pm 0.00^{\mathrm{a}}$ & $3.60 \pm 0.10^{\mathrm{a}}$ \\
Water & $19.32 \pm 3.58^{\mathrm{b}}$ & $0.03 \pm 0.02^{\mathrm{a}}$ & $4.25 \pm 0.01^{\mathrm{c}}$ \\
\hline
\end{tabular}

${ }^{1)}$ Values are mean \pm SD $(n=3)$.

${ }^{2)}$ Values with different superscript within the same column are significantly different $(p<0.05)$.

${ }^{3)}$ Concentration of sample solution is $500 \mathrm{ppm}$.

\section{총 폴리페놀, 총플라보노이드 및 총 펙틴}

고추냉이 잎 $80 \%$ 에탄올 추출물의 각 분획물 중 총 폴리 페놀 함량은 chloroform 분획물, ethyl acetate 분획물이 각각 $56.42 \mathrm{mg} \mathrm{GAE} / \mathrm{g}, 56.24 \mathrm{mg} \mathrm{GAE} / \mathrm{g}$ 로 높았으며 다음으로 n-butanol 분획물 $41.59 \mathrm{mg} \mathrm{GAE} / \mathrm{g}$, 물 분획물 $26.43 \mathrm{mg}$ $\mathrm{GAE} / \mathrm{g}$ 의 순이었으며 $\mathrm{n}$-hexane 분획물 $13.29 \mathrm{mg} \mathrm{GAE} / \mathrm{g}$ 으 로 가장 낮았다(Table 2). 총 플라보노이드 함량은 n-hexane, 
chloroform, ethyl acetate, n-butanol, 물 분획물이 각각 38.70 $\mathrm{mg} \mathrm{GAE} / \mathrm{g}, 92.21 \mathrm{mg} \mathrm{GAE} / \mathrm{g}$. $97.29 \mathrm{mg} \mathrm{GAE} / \mathrm{g}, 104.16 \mathrm{mg}$ $\mathrm{GAE} / \mathrm{g}, 30.16 \mathrm{mg} \mathrm{GAE} / \mathrm{g}$ 으로 나타났다. Park과 Lee(21)는 고추냉이 잎 추출물에 함유된 페놀성 화합물의 함량 차이가 항산화 활성에 큰 영향을 준다고 하였다. 펙틴 함량은 n-hexane chloroform, ethyl acetate, n-butanol, 물 분획물이 각각 $33.30 \mathrm{mg} / \mathrm{g}, 133.18 \mathrm{mg} / \mathrm{g}, 108.80 \mathrm{mg} / \mathrm{g}, 14.43 \mathrm{mg} / \mathrm{g}$, $90.12 \mathrm{mg} / \mathrm{g}$ 을 나타내었으며 chloroform 분획물에서 가장 높은 값을 나타내었다. Chloroform 분획전 지용성 hexane 분획에서는 상대적으로 함량이 낮았다. 이러한 펙틴은 고 추냉이 잎을 첨가물로 활용하여 식품의 점도 증가 및 겔 형성에 영향을 줄 수 있다고 하였다(12).

Table 2. Total polyphenol, total flavonoid, and total pectin of solvent fractions from $80 \%$ ethanol extract of Wasabia koreana Nakai leaf

\begin{tabular}{cccc}
\hline Fraction & $\begin{array}{c}\text { Total polyphenol } \\
(\mathrm{mgGAE} / \mathrm{g})\end{array}$ & $\begin{array}{c}\text { Total flavonoid } \\
(\mathrm{mgNE} / \mathrm{g})\end{array}$ & $\begin{array}{c}\text { Total pectin } \\
(\mathrm{mg} / \mathrm{g})\end{array}$ \\
\hline n-Hexane & $13.29 \pm 0.43^{1 \mathrm{la} 2)}$ & $38.70 \pm 0.48^{\mathrm{a}}$ & $33.30 \pm 1.48^{\mathrm{b}}$ \\
Chloroform & $56.42 \pm 3.7^{\mathrm{d}}$ & $92.21 \pm 6.19^{\mathrm{b}}$ & $133.18 \pm 11.23^{\mathrm{e}}$ \\
Ethyl acetate & $56.24 \pm 1.55^{\mathrm{d}}$ & $97.29 \pm 5.40^{\mathrm{b}}$ & $108.80 \pm 6.77^{\mathrm{d}}$ \\
n-Butanol & $41.59 \pm 1.24^{\mathrm{c}}$ & $104.16 \pm 8.93^{\mathrm{b}}$ & $14.43 \pm 1.23^{\mathrm{a}}$ \\
Water & $26.43 \pm 0.35^{\mathrm{b}}$ & $30.16 \pm 0.37^{\mathrm{a}}$ & $90.12 \pm 2.78^{\mathrm{c}}$ \\
\hline
\end{tabular}

${ }^{1)}$ Values are mean \pm SD $(n=3)$.

${ }^{2)}$ Values with different superscript within the same column are significantly different $(p<0.05)$

A

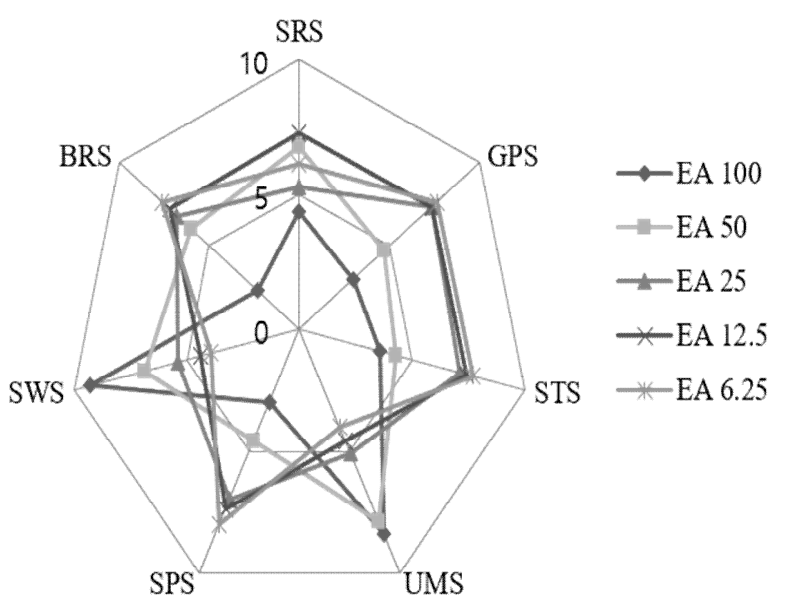

전자혀

고추냉이 잎 $80 \%$ 에탄올 추출물을 용매로 분획하여 각 분획물 중 ethyl acetate 분획물과 물 분획물의 신맛, 짠맛, 감칠맛, 단맛, 쓴맛 등 5 가지 맛 감별용 전자혀 기기 측정 결과는 Fig. 1과 같다. Ethyl acetate 분획물의 $100 \mathrm{ppm}$ 농도 는 감칠맛에서 가장 높았고, 신맛에서 가장 낮았다. 감칠맛 의 강도는 분획물의 농도가 증가할수록 높았다(Fig. 1A). 물 분획물의 $100 \mathrm{ppm}$ 농도는 짠맛에서 가장 높았고 신맛과 감칠맛에서 가장 낮았다(Fig. 1B). 분획물 $100 \mathrm{ppm}$ 은 다른 저농도와 뚜렷한 차이를 나타내었다. 페놀산으로 gallic acid와 p-hydroxybenzoic acid, 플라보노이드로 $(+)$ catechin 과 naringin을 사용하여 그 페놀성 화합물의 농도를 100 $\mathrm{ppm}, 50 \mathrm{ppm}, 25 \mathrm{ppm}, 12.5 \mathrm{ppm}, 6.25 \mathrm{ppm}$ 의 농도로 제조하 여 측정 결과는 Fig. 2와 같다. 페놀성 화합물은 배당체 혹은 비배당체로 존재하여 맛에 영향을 주며 페놀산, 플라 보노이드, 탄닌 등 구조에 따라 맛 성분의 차이가 크다. 각 페놀성 화합물의 농도가 증가함에 따라 단맛은 증가하고 반대로 신맛은 감소하는 것으로 나타났다. 이러한 농도 의 존적 증감 경향은 짠맛, 감칠맛, 쓴맛으로 갈수록 일정하지 않았다. (+)catechin(Fig. 2A)과 p-hydroxybenzoic acid(Fig. $2 \mathrm{C}$ )는 농도가 증가할수록 더 약하게 나타난 반면 도토리와 감귤의 쓴맛 성분으로 알려진 gallic acid(Fig. 2B)와 naringin(Fig. 2D)은 감칠맛을 제외하고 쓴맛을 포함한 맛 성분에서 농도 의존적으로 증가하는 것으로 나타났다. 즉 Naringin의 경우 신맛이 N100 ppm(9.6), N50 ppm(6.1), N25 $\operatorname{ppm}(5.4), \mathrm{N} 12.5 \mathrm{ppm}(4.8), \mathrm{N} 6.25 \mathrm{ppm}(4.2)$ 의 순으로 높았 다. 고추냉이 잎 ethyl acetate 분획물과 물 분획물 각각의

B

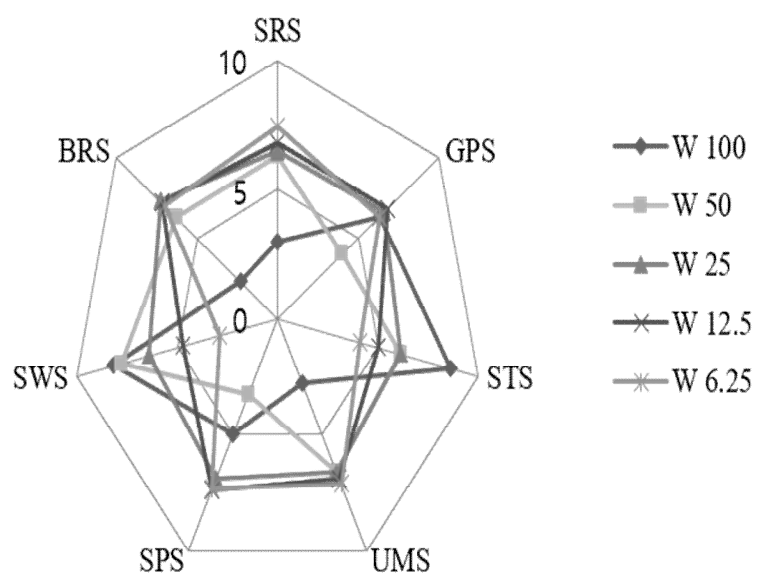

Fig. 1. Electronic tongue analysis of taste characteristics of different fractions from $80 \%$ ethanol extract of Wasabia koreana Nakai leaf. A, ethyl acetate fraction; B, water fraction

EA100, ethyl acetate fraction $100 \mathrm{ppm}$; EA 50, ethyl acetate fraction $50 \mathrm{ppm}$; EA25, ethyl acetate fraction $25 \mathrm{ppm}$; EA12.6, ethyl acetate fraction $12.5 \mathrm{ppm}$; EA6.25, ethyl acetate fraction $6.25 \mathrm{ppm}$; W100, water fraction $100 \mathrm{ppm}$; W50, water fraction $50 \mathrm{ppm}$; W25, water fraction $25 \mathrm{ppm}$; W12.5, water fraction $12.5 \mathrm{ppm}$; W6.25, water fraction 6.25 ppm; SRS, sourness; GPS, sourness-saltiness-metallic; STS, saltiness; UMS, umami; SPS, metallic-spiciness-umami; SWS, sweetness; BRS, bitterness. 
A

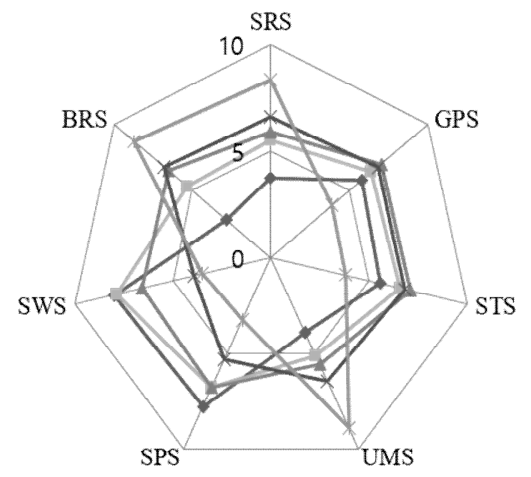

$\mathrm{C}$

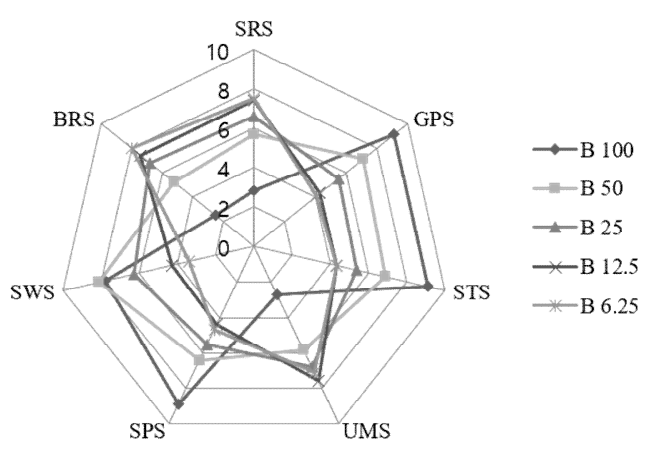

B

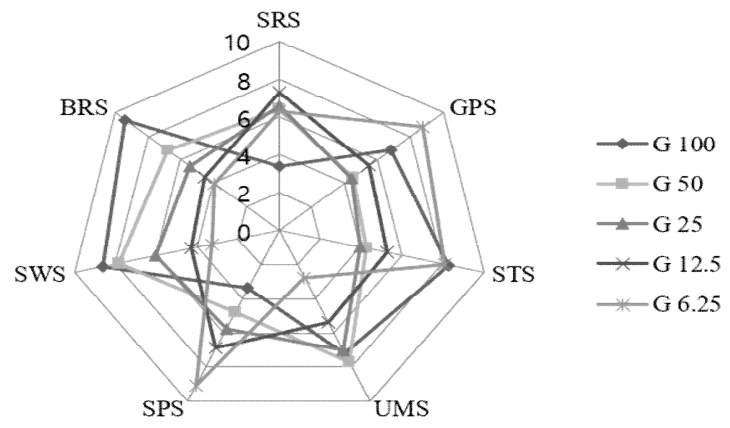

$\mathrm{D}$

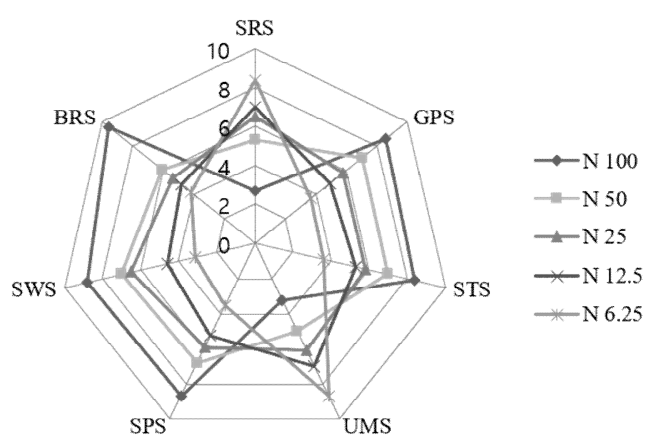

Fig. 2. Electronic tongue analysis of taste characteristics of catechin (A), gallic acid (B), p-hydroxybenzoic acid (C), naringin (D) from different concentration. Radar fingerprints of electronic tongue sensors of phenolic compounds.

C100, (+)catechin 100 ppm; G100, gallic acid 100 ppm; B100, p-hydroxybenzoic acid 100 ppm; N100, naringin 100 ppm; SRS, sourness; GPS, sourness-saltiness-metallic; STS, saltiness; UMS, umami; SPS, metallic-spiciness-umami; SWS, sweetness; BRS, bitterness.

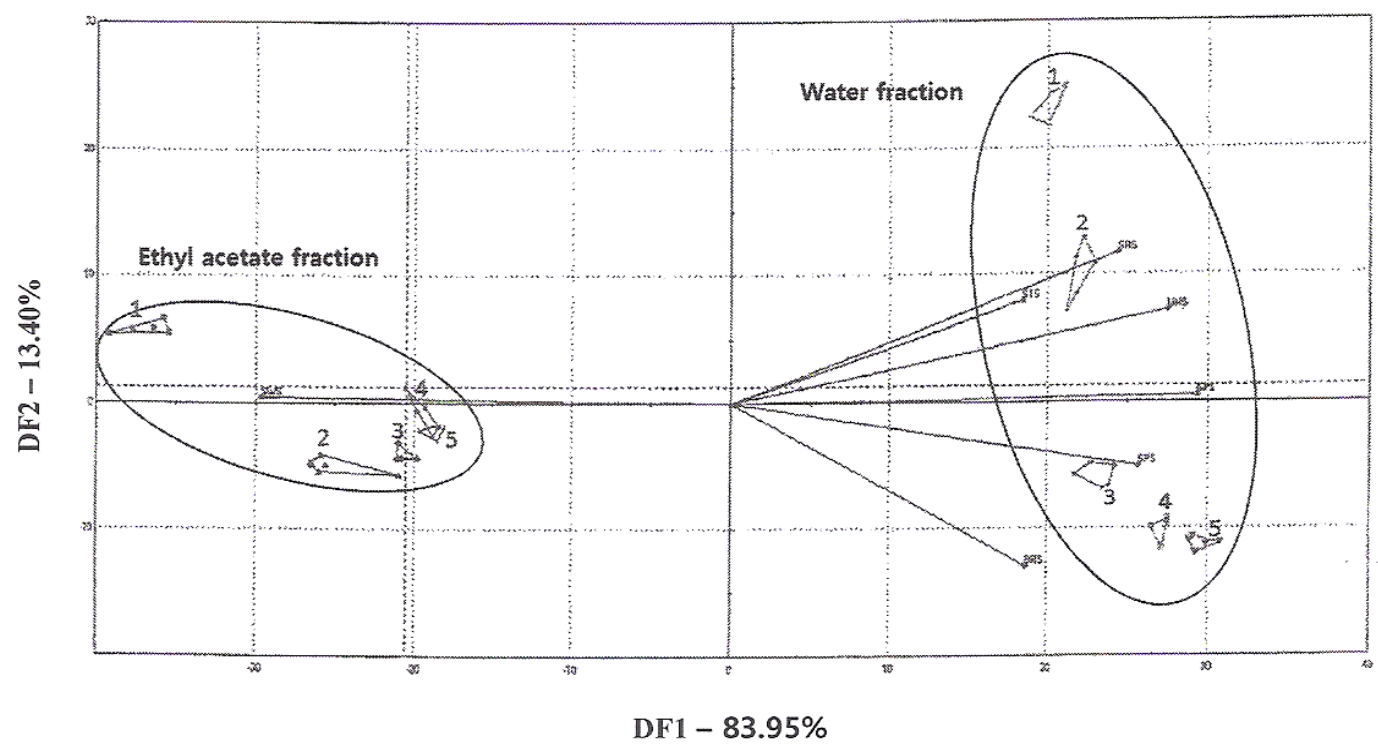

Fig. 3. Discriminant function analysis of the obtained data of different fractions from $80 \%$ ethanol extract of Wasabia koreana Nakai leaf by taste sensors based on electronic tongue.

1, 100 ppm; 2, 50 ppm; 3, 25 ppm; 4, 12.5 ppm; 5, 6.25 ppm. 
분포 특성을 판별함수분석(DFA, discriminant function analysis)인 Fig. 3 에 나타내었다. DF1(83.96\%)에 양의 상관 관계인 물 분획물과 음의 상관관계인 ethyl acetate 분획물의 농도 의존적 군집이 확인되었다. DF2(13.40\%)에 농도가 높아질수록 양의 상관관계를 얻을 수 있었다. Fig. 4는 $\mathrm{DF} 1(60.86 \%)$ 에 양의 상관관계인 gallic acid, naringin의 농 도 의존적 군집이 확인되었으며 $\mathrm{DF} 2(17.82 \%)$ 에 플라보노 이드인 catechin과 naringin은 음의 상관관계의 결과를 확인 할 수 있었다. Kim 등(23)의 연구에 의하면 전자혀를 통한 각 부위의 맛 성분 분석으로 식품소재로서 이용 가능하다고 했으며, 본 분획물과 페놀성 화합물의 종류별 그리고 농도 별 맛 성분에 미치는 영향에 대한 추가 실험이 요구된다.
DPPH radical 소거능, ABTS radical 소거능

$\mathrm{DPPH}$ radical 소거능은 고추냉이 잎 $80 \%$ 에탄올 추출물 을 n-hexane, chloroform, ethyl acetate, n-butanol의 용매로 분획하여 각 분획층에 따른 항산화 활성을 비교한 것으로 Table 3과 같다. DPPH 라디칼 소거활성을 나타내는 $\mathrm{IC}_{50}$ 은 n-hexane chloroform, ethyl acetate, n-butanol, water 분획물 이 각각 $12,667.20 \mathrm{ppm}, 1,591.71 \mathrm{ppm}, 899.88 \mathrm{ppm}, 522.06$ $\mathrm{ppm}, 3,252.91 \mathrm{ppm}$ 을 나타내어 $\mathrm{n}$-butanol 분획물에서 가장 높은 항산화성을 보였다. Lee 등(24)의 연구에 따르면 연근 추출물을 유기용매별 분획물의 DPPH radical 소거능 결과 $\mathrm{n}$-hexane층에서 가장 높게 나타났으며 그 다음으로 물층에 서 높은 항산화성을 나타낸다고 했다. Sung(21)은 고추냉이

Table 3. Electron donating ability and ABTS radical scavenging ability of solvent fractions from $80 \%$ ethanol extract of Wasabia koreana Nakai leaf

\begin{tabular}{|c|c|c|c|c|}
\hline \multirow{2}{*}{ Fraction } & \multicolumn{2}{|c|}{ DPPH IC S0 $_{50 m)}$} & \multicolumn{2}{|c|}{ ABTS IC S0 $_{50}(\mathrm{ppm})$} \\
\hline & Wasabia sample & Ascorbic acid & Wasabia sample & Ascorbic acid \\
\hline n-Hexane & $12,667.20 \pm 1033.98^{1)(2)}$ & & $3,103.04 \pm 619.82^{\mathrm{c}}$ & \\
\hline Chloroform & $1,591.71 \pm 249.36^{\mathrm{a}}$ & & $632.50 \pm 23.36^{\mathrm{ab}}$ & \\
\hline Ethyl acetate & $899.88 \pm 55.99^{\mathrm{a}}$ & $41.93 \pm 3.11$ & $276.63 \pm 2.29^{\mathrm{a}}$ & $39.07 \pm 4.17$ \\
\hline n-Butanol & $522.06 \pm 56.45^{\mathrm{a}}$ & & $171.99 \pm 22.87^{\mathrm{a}}$ & \\
\hline Water & $3,252.91 \pm 87.12^{b}$ & & $1,022.08 \pm 128.78^{b}$ & \\
\hline
\end{tabular}

${ }^{1)}$ Values are mean $\pm \mathrm{SD}(\mathrm{n}=3)$.

${ }^{2)}$ Values with different superscript within the same column are significantly different $(\mathrm{p}<0.05)$.

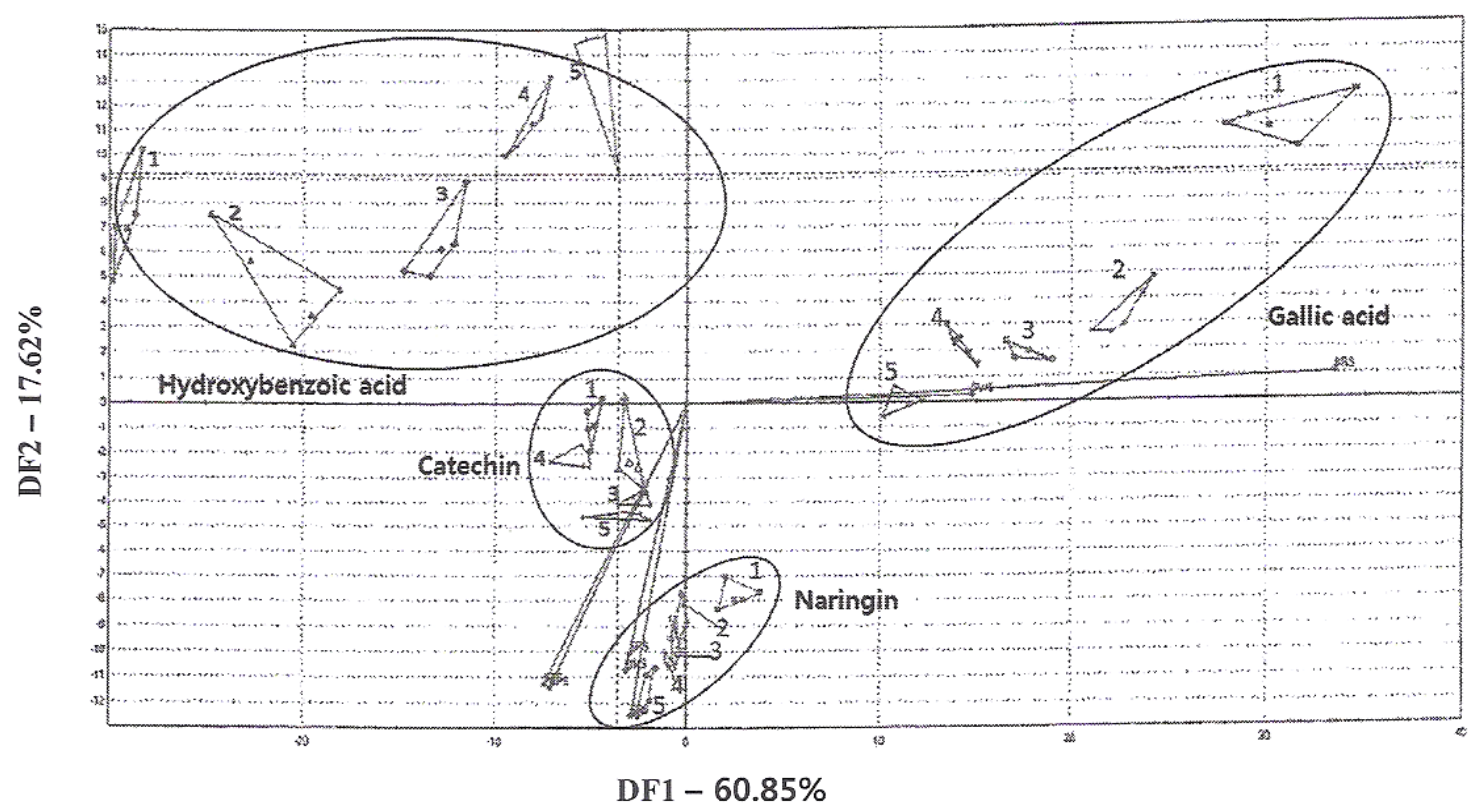

Fig. 4. Discriminant function analysis of the obtained data of (+)catechin, gallic acid, p-hydroxybenzoic acid, naringin from different concentration by taste sensors based on electronic tongue.

1, 100 ppm; 2, 50 ppm; 3, 25 ppm; 4, 12.5 ppm; 5, 6.25 ppm. 
열수추출물의 물 분획물에서 가장 높은 항산화성을 나타낸 다고 보고하여 본 실험의 결과와 다른 경향을 보였다.

ABTS 라디칼 소거활성은 n-hexane chloroform, ethyl acetate, n-butanol, 물 분획물의 $\mathrm{IC}_{50}$ 값이 각각 $3,103.04 \mathrm{ppm}$, $632.50 \mathrm{ppm}, 276.63 \mathrm{ppm}, 171.99 \mathrm{ppm}, 1,022.08 \mathrm{ppm}$ 으로 $\mathrm{n}$-butanol 분획물에서 가장 높은 항산화성을 보였다. 각 분 획의 $\mathrm{IC}_{50}$ 값은 양성대조구인 ascorbic acid의 $39.07 \mathrm{ppm}$ 과 큰 차이를 보여 항산화성이 낮음을 알 수 있다. 그러나 분획 물간 비교시 물 분획의 경우 추출수율(Table 1)이 높아 총량 면에서는 페놀성 화합물의 함량과 항산화 활성은 증가할 것으로 생각되며 분획별 용도를 달리하는 부가가치 제품의 개발이 가능할 것으로 생각된다.

\section{요 약}

본 연구는 고추냉이 엽병을 포함한 고추냉이 잎의 $80 \%$ 에탄올 추출물로부터 $\mathrm{n}$-hexane, chloroform, ethyl acetate, n-butanol, water 순으로 순차 추출하여 그 분획물의 수율, 탁도, $\mathrm{pH}$, 총 폴리페놀, 총 플라보노이드, 총 펙틴을 분석하 고 전자혀 분석, DPPH 라디칼 소거능, $\mathrm{ABTS}$ 라디칼 소거 등을 조사하였다. 수율은 물 분획이 가장 높게 나타났으며, $\mathrm{pH}$ 도 물 분획이 4.25로 높게 나타났다. Ethyl acetate 분획에 서 총 폴리페놀, 총 플라보노이드, 총 펙틴 함량은 각각 $56.24 \mathrm{mg} \mathrm{GAE} / \mathrm{g}, 97.29 \mathrm{mg} \mathrm{NE} / \mathrm{g}, 108.80 \mathrm{mg} / \mathrm{g}$ 을 나타내었 다. 이는 고추냉이 잎과 엽병으로부터 얻어진 용매 분획물 의 페놀성 화합물과 펙틴 등의 추출 수율에 유의적인 차이 가 있음을 알 수 있다. 전자센서에 의한 ethyl acetate 분획과 물 분획의 맛 성분의 분석은 판별함수분석(DFA)도에서 $\mathrm{DF1}(83.96 \%)$ 에 양의 상관관계인 물 분획과 음의 상관관계 인 ethyl acetate 분획의 농도 의존적 군집이 확인되었다. Ethyl acetate 분획에 있어서 DPPH 라디칼 소거능과 ABTS 라디칼 소거능의 $\mathrm{IC}_{50}$ 값이 각각 $899.88 \mathrm{ppm}, 276.63 \mathrm{ppm}$ 을 나타내었다. 따라서 활용도가 낮은 고추냉이 잎으로부터 에탄올 추출물 및 그 분획물은 맛 성분과 항산화 활성의 향상을 통한 고부가가치 제품의 개발을 위한 소재로 사용될 것으로 생각된다.

\section{감사의 글}

본 과제는 교육부의 재원으로 한국연구재단의 지원을 받아 수행된 사회맞춤형 산학협력선도대학 육성사업의 연 구결과입니다.

\section{References}

1. Park KS, Park HW, Shin IS, Lee JH, Seo HW (2009) Study on comparison of antimicrobial activity between horseradish (Armoracia rusticana) root extracts and synthetic allyl isothiocyanate against oral pathogenic microorganisms. J Korean Acad Pediatr Dent, 36, 217-226

2. Hosoya T, Yun YS, Kunugi A (2005) Five novel flavonoids from Wasabia japonica. Tetrahedron, 61, 7037-7044

3. Hur JM, Lee JH, Choi JW, Hwang GW, Chung SK, Kim MS, Park JC (1998) Effect of methanol extract and kaempferol glycosides from Armoracia rusticana on the formation of lipid peroxide in bromobenzene-treated rats in vitro. Kor J Pharmacogn, 29, 231-236

4. Hosoya T, Yun YS, Kunugi A (2008) Antioxidant phenylpropanoid glycosides from the leaves of Wasabia japonica. Phytochemistry, 69, 827-832

5. Manach C, Scalbert A, Morand C, Remesy C, Jimenez L (2004) Polyphenols: food sources and bioavailability. Am J Clin Nutr, 79, 727-747

6. Pandey KB, Rizvi SI (2009) Plant polyphenols as dietary antioxidants in human health and disease. Oxid Med Cell Longevity, 2, 270-278

7. Park YY, Cho MS, Park S, Lee YD, Jeong BR, Chung JB (2006) Sinigrin contents in different tissues of wasabi and antimicrobial activity of their water extracts. Kor J Hort Sci Technol, 24, 480-487

8. Rha YA, Park JN, Na YS (2004) The effects of pine pollen and horseradish on fermentation of Kimchi. Korean J Culinary Res, 10, 178 - 189

9. Kim HS, Hong MJ, Kang IY, Jung JY, Kim HK, Shin YS, Jun HJ, Suh JK, Kang YH (2009) Radical scavenging activities and antioxidant constituents of oriental melon extract. J Bio-Environ Control, 18, 442-447

10. Basiri S, Shekarforoush SS, Aminlari M, Akbari S (2015) The effect of pomegranate peel extract (PPE) on the polyphenol oxidase (PPO) and quality of pacific white shrimp (Litopenaeus vannamei) during refrigerated storage. LWT-Food Sci Tech, 60, 1025-1033

11. Park M, Chang MS, Jeong MC, Kim GH (2013) Scutellaria baicalensis extracts as natural inhibitors of food browning. J Korean Soc Food Sci Nutr, 42, 792-799

12. Sung EH, Shin SM, Kang YH (2017) Physicochemical quality characteristics and antioxidant activity of Wasabi (Wasabia japonica) leaf and petiole extracts. J Korean 
Soc Food Sci Nutr, 46, 335-342

13. Kim EJ, Kim JH (2015) Physiological activities of water extract and solvent fractions of Grifola frondosa. J Mushrooms, 13, 192-198

14. Kim SE, Lee SW, Yeum DM, Lee MJ (2012) Quality characteristics of tofu with added alfalfa (Medicago sativa L.) extracts. J Korean Soc Food Sci Nutr 41, 123-128

15. Lee HJ, Sung JH, Choi JY, Cho JS, Lee YM, Chung HS, Moon KD (2016) Evaluation of the quality characteristics in omija (Schizandra chinensis Baillon) power tea. Korean J Food Sci Technol, 48, 42-47

16. Pinto MDS, Lajolo FM, Genovese MI (2007) Bioactive compounds and antioxidant capacity of strawberry jams. Plant Foods Hum Nutr, 62, 127-131

17. McComb EA, McCready RM (1952) Colorimetric determination of pectic substances. Anal Chem, 24, 1630-1632

18. Suh YS, Lee SH, Shang Y, Yoon JR, Lee WJ (2014) Changes in antioxidant activities and flavor patterns of Coffea arabica beans during roasting. Korean J Food Preserv, 21, 224-230
19. Blois MS (1958) Antioxidant determinations by the use of a stable free radical. Nature, 181, 1199-1200

20. Kim JH, Lee SH (2016) Antioxidative and antimicrobial activities of Oenotherabiennis extracted by different methods. Korean J Food Preserv, 23, 233-238

21. Sung EH (2017) Physicochemical quality characteristics and antioxidant activity of water extract and solvent fraction of Wasabi (Wasabia japonica). MS Thesis, Gangneung-Wonju National University, Korea, p 49-52

22. Park SJ, Lee HY (2015) Component analysis and antioxidant activity of Wasabi japonica Matsum leaves. Korean J Medicinal Crop Sci, 23, 207-213

23. Kim HS, Woo SM, Shin EC (2018) Physicochemical properties and taste measurement using an electronic sensor in Wasabia koreana Nakai. J Korean Soc Food Sci Nutr, 47, 1144-1152

24. Lee JJ, Ha JO, Lee MY (2007) Antioxidative activity of lotus root (Nelumbo nucifera G.) extracts. J Life Sci, 17, 1237-1243 